house a large, multidisciplinary team of DoE scientists and an unmatched array of equipment for use by them and by visiting university scientists.

The new programme and laboratory are supposed to bring first-rate science and new ideas to bear on clean-up for the first time. But a formidable array of barriers that have so far kept science out of the programme will have to be overcome.

First, relations between scientists and the engineering contractors who operate the clean-up programme are not good. "There's a lot of them would like us out there with shovels," says one EMSL chemist of the contractors. Many engineers on the sites view basic scientific research as an indulgence. Investment in research, they correctly surmise, implies that their current approach is inadequate, even misguided. As one Hanford engineer sees it, the research arm of DoE "wants the best science. [It is] not particularly interested in solving anyone's problems."

The tension between the two camps has been exacerbated by less than cordial relations between the Office of Energy Research (OER), DoE's science arm, and the Office of Environmental Management. Mutual mistrust goes back to the foundation of OEM in 1989, when money for science was transferred from OER to the new office, according to some scientists, but then spent on other things. At the launch of the new, jointly administered science programme on 14 February, Grumbly and Martha Krebs, who heads OER, exchanged Valentine cards, implicitly conceding just how bad relations had been.

"There has been very little connection between what OER does and what OEM needs," says Roy Gephart, a geohydrologist at PNNL who has been closely involved with the new science programme. Partly as a result, he says, there has been little flow of new science and technology into the clean-up programme. "Technology transfer is spoken about often, but it is not going on in any effective way."

Pointing to the situation at Hanford, Gephart asks: "What do you see there? $\$ 1$ billion has been spent on 'technology development' across the DoE complex, and what do we have to show for it? We should be able to go out on site and see demonstration after demonstration [of new technologics]. But very, very few are occurring."

Gephart believes that, if more money is invested in the right kinds of research, and better links are established to develop the output of that science into solutions, "a whole series of in situ technologies that will reduce costs and risks" associated with waste on the DoE sites could result.

These would include bioremediation, using enzymes to attack groundwater contamination; chemical treatments to convert mobile, soluble ions of toxic elements into non-soluble ones which precipitate out and stay put; and development (to page 379)

\title{
Russian waste goes to ground
}

Washington. On 29 September 1957, a vast explosion rocked the main Soviet plutonium production facility near the city of Chelyabinsk in western Siberia. The blast, which was equivalent to 100 tonnes of TNT and released two million curies of radiation over a hundred-mile tract of neighbouring farmland, was caused by the overheating of a mixture

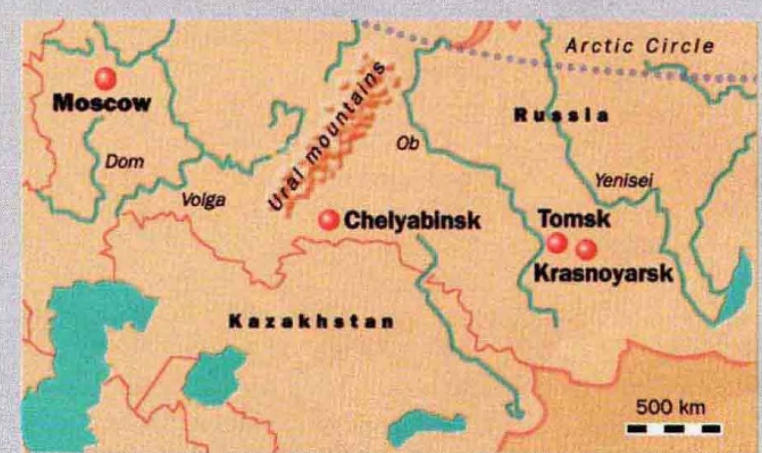

Russia's weapons complex in western Siberia harbours far greater clean-up problems than US sites.

of sodium nitrate and sodium acetate in a waste tank.

For both the Soviet Union and the United States - which learned of the accident through its espionage network, but released no information to the public - the explosion served as a timely warning of both the volatility and potential danger of high-level nuclear waste.

The Soviet weapons complex, built hurriedly by Stalin and his secret police chief, Lavrenti Beria, has many features in common with that of the United States. Plutonium was produced at three sites in western Siberia - first at Mayak near Chelyabinsk, and later at Tomsk and Krasnoyarsk (see figure).

\section{Radiation released}

But, according to scientists in both countries, the scale of the environmental crisis left behind with the ending of weapons production is far greater in the Soviet complex, with perhaps 100 times as much radioactivity released from the sites. "It's far, far worse than what the United States did," says Stan Norris, a nuclear weapons expert at the Natural Resource Defense Council in Washington $\mathrm{DC}$, of radiation releases that were allowed to take place in the Soviet complex during weapons production.

Unlike the United States, which closed the last of the reactors used to produce plutonium for weapons in 1988 , Russia is still operating several of its reactors - which also generate electricity - and is not spending billions of dollars a year on environmental remediation. "In terms of what we're doing in clean-up, they don't have a programme," says Norris.

In the early and very desperate days of the Soviet weapons programme, highlevel waste was drained straight into the Techa River at Mayak. But this had stopped by 1953 , and the waste was put in tanks, and later dumped in nearby Lake Karachai. "They weren't totally careless," says Norris. "They knew that they were handling toxic and dangerous materials." But the measures taken to protect the population from these materials were, by Western standards, minimal.

Work started quite early on vitrification of the tank waste; pilot plant was built in the 1970 s, followed by full-scale plant which has turned 250 million curies - one-quarter of Mayak's tank waste - into glass for temporary storage above ground.

Contaminated lakes and rivers around Mayak have been receiving political attention for some time. The previous president, Mikhail Gorbachev, for example, set up a commission to examine problems at the site, and special laws have since been enacted to protect the environment there. Efforts are continuing to stabilize radioactive contamination in Lake Karachai, using concrete blocks to hold contaminated mud in place.

At the two other plutonium production facilities in Russia - further east, and away from centres of population - highlevel waste is disposed of by being pumped directly into deep wells. This practice, which would be politically as well as legally unacceptable in the United States, has been used to dispose of around 2 billion curies of radioactive waste at the two sites - ten times more than the waste inventory of the Hanford tanks, and almost 1,000 times as much as has been released into the environment by the entire US complex.

Russian scientists have defended deep-well disposal, arguing that the waste will decay before it escapes. But public protest halted a plan for deep-well injection at Krasnoyarsk in 1989.

Minatom, Russia's nuclear agency, has signed an agreement with the US Department of Energy to share waste management and clean-up technologies. But according to Alexei Yablokov, director of the Centre for Environmental Policy, an independent group in Moscow, the situation in the Soviet complex is continuing to deteriorate.
C. $M$. 